\title{
Hypothesis
}

\section{Succinylcholine, cholinoceptors and catecholamines: Proposed mechanism of early adverse haemodynamic reactions}

\begin{abstract}
An hypothesis is proposed to account for the occurrence of adverse haemodynamic reactions to succinylcholine. Interaction of succinylcholine with cholinergic receptors is posrulated to result in release of endogenons catechola. mines (predominantiy norepinephrine). The occurrence and the clinical manifestations of the adverse reactions would be dependent on the extent of the release. Based on literature reports of findings in experimental animals with nicotinic and muscarinic agents, a mechanism for the release of norepinephrine is oullined. Interaction of succinylcholine with muscarinic and nicotinic receptors is proposed to result in an initial activation which is jollowed by a phase of chemical insensirivity. Activation of the presynaptic nicotinic receptors on the pastganglionic sympathetic terminais leads to a short-lasting release of norepinephrine. Activation of the presynaptic muscarinic
\end{abstract}

\section{Key words}

COMPLICATIONS: arrhythmias, succinylcholine; NEUROMUSCULAR RELAXANTS: succinylcholine; SYMPATHETIC NERVOUS SYSTEM: catecholamines, cholinoceptors; PARASYMPATHETIC NERVOUS SYSTEM: cholinoceptors.

From the Departments of Anesthesiology and Pharmacology, Medical College of Ohio, Toledo, Ohio, USA.

Address correspondence to: $\mathrm{V}$. Nigrovic, Department of Anesthesiology, Medical College of Ohio, C. S. 10008, Toledo, Ohio 43699 U.S.A. receptors produces attenuation of the norepinephrine release. In the majority of patients these opposing actions are balanced and the net result is small, variable, and of little clinical importance. An unbalanced response leading to clinical manifestations can be expected if the nwo types of the presynaptic cholinoceptors are differentialty activated.

In the vast majority of patients the administration of succinylcholine is not accompanied by clinically significant adverse reactions. In a minority of patients, however, undesired cardiovascular effects of variable magnitude and severity have been observed and recently reviewed. ${ }^{1-9}$ Information about the mechanisms producing these adverse reactions is sparse or lacking.

The purpose of this article is threefold:

I. To describe briefly the adverse cardiovascular effects of succinylcholine and their reputed causes.

II. To present the hypothesis that the adverse reactions to succinylcholine are attributable, at least in part, to the interaction between succinylcholine and the specific cholinergic receptors.

III. To interpret the effects noted under 1 in terms of the proposed hypothesis.

I. Early adverse cardiovascular effects of succinylcholine

Minor alterations of heart rate and blood pressure are commonly observed after bolus intravenous 
administration of succinylcholine $\left(1 \mathrm{mg} \cdot \mathrm{kg}^{-1}\right)$. Initial bradycardia is followed by the retum of the heart rate to normal (i.e., preinjection) or to slightly higher levels. In infants, bradycardia is observed after the intravenous ${ }^{11}$ but not after the intramuscular injection of succinylcholine. ${ }^{12.13}$ Bradycardia in adults is more pronounced after the second or subsequent doses of succinylcholine, ${ }^{14}$ especially if the time interval between the two doses is in the range of two to five minutes. ${ }^{15,16} \mathrm{~A}$ slow intravenous infusion of succinylcholine is seldom accompanied by cardiovascular alterations. ${ }^{17,18}$

The mechanism leading to these cardiovascular effects of succinylcholine is not clear. Most reports attribute bradycardia to the stimulation of the muscarinic receptors present in the sino-atrial node. This can clearly not be the sole explanation since it does not account for the more frequent incidence of bradycardia either in children or after repeated injection. The claim that children are "relatively sympathicotonic individuals" was not substantiated and is not convincing. Neither is the postulate that metabolites of succinylcholine (succinylmonocholine and choline) sensitize the heart to subsequent doses

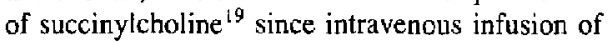
equal or larger amounts of succinylcholine does not produce such "sensitization." Moreover, this proposal does not provide an explanation for bradycardia in children or for the relatively short time period when the administration of the second dose of succinylcholine is especially apt to cause bradycardia in adults. The fact that atropine, a muscarinic blocking agent, is effective for the prevention of the bradycardic response in clinical practice does not help clarify the pharmacologic problem. Atropine prevents activation of the cardias muscarinic receptors and thus only permits an unopposed expression of the extant sympathetic activity.

Severe haemodynamic crises, including cardiac arrest, have been reported in patients with burns, tetanus, spinal cord transection, or lower motor neuron injury ${ }^{20}$ and, more recently, in a patient after irradiation. ${ }^{21}$ Increased serum potassium has been observed frequently during these crises. ${ }^{20}$ Cardiovascular collapse has been conveniently ascribed to this hyperkalaemic response, sometimes even in the absence of documented hyperkalaemia. ${ }^{22}$ A mechanism leading to hyperkalaemia has been outlined for patients with lower motor neuron lesions (denervation) ${ }^{20}$ but not for the other clinical situations.
Pretreatment of patients with different pharmacologic agents is employed, with variable benefits, to attenuate adverse reactions to succinylcholine that are not related to the cardiovascular system. For this purpose a small dose of a non-polarizing muscle relaxant, ${ }^{23-25}$ lidocaine, ${ }^{26,27}$ diazepam ${ }^{28-31}$ or succinylcholine itself ("self-taming") ${ }^{32}$ have been used. Conspicuously, the effects of such pretreatment on the cardiovascular effects of succinylcholine were not tested. A small dose of d-tubocurarine was, however, reported to prevent bradycardia from the second dose of succinylcholine ${ }^{33,34}$ As an explanation, Mathias et al. ${ }^{34}$ proposed the bradycardia represents the reflex response to stimulation of the baroreceptors by succinylcholine; d-tubocurarine would prevent this stimulation without affecting the heart directly. Nevertheless, this very attractive interpretation still does not explain why the second dose of succinylcholine causes bradycardia more often than does the first nor why bradycardia occurs more frcquently in children.

\section{Interaction of succinylcholine with cholinergic receptors: the proposed hypothesis}

\section{Statement of the hypothesis:}

Succinylcholine produces a release of endogenous catecholamines. The interplay among the effects produced by the liberated catecholamines, the anaesthetic agent, and the pronounced hyperkalaemia (if present) determines the occurrence and the clinical pattem of the early adverse haemodynamic reactions.

The presentation of the hypothesis will proceed from the description of the basic pharmacologic information about cholinoceptors and catecholamines, to the exposition of the hypothesis, and finally, to the interpretation of the previously reviewed clinical observations.

\section{Cholinergic drugs and cholinoceptors}

Succinylcholine causes a failure of neuromuscular transmission by interacting with the postsynaptic nicotinic receptor on the endplate. ${ }^{35}$ The initial reaction is the depolarization of the endplate (initial stimulation) followed by the inability of the endplate to respond to subsequent stimulation by acetylcholine (muscle paralysis). This sequence of events - an initial stimulation and a subsequent inhibition - is also observed with some other drugs that interact with nicotinic receptors. Nicotine itself 
is the best known example of these agents and its very complex pharmacologic and toxic effects are due to such a biphasic reaction of the nicotinic receptors. ${ }^{36}$ When administered to animals, nicotine produces muscle paralysis, a contracture of denervated skeletal muscles, and alterations in blood pressure and heart rate. ${ }^{36-38}$ The similarity of these responses to those of succinylcholine is obvious. Interaction of nicotine with receptors in the autonomic ganglia and in the striated muscles, facilitation of ganglionic transmission, ${ }^{39}$ and stimulation of the nicotinic receptors on the sensory terminals of the autonomic afferents ${ }^{37}$ account for many of these effects. Nicotine also elicits pharmacologic responses in isolated tissues devoid of ganglionic cells: nicotine or acetylcholine (the latter in the presence of atropine) produce both positive chronotropic and positive inotropic effects in isolated heart preparations, ${ }^{40.41}$ contracture of the isolated spleen, ${ }^{42}$ and constriction of the isolated middle ear artery of the rabbit. ${ }^{4 \hat{3}, 44}$ All of these effects in isolated organs are explained by the nicotine-induced release of catecholamines, predominantly norepinephrine.

Taking the isolated rabbit heart preparation as a model, the following phenomena have been observed:

(a) The release of norepinephrine occurs as a burst immediately on exposure to a nicotinic agent. The release is short-lived even though perfusion with the agonist is continued ("explosive release"). ${ }^{45}$ Norepinephrine, rather than its metabolic products, constitutes the major fraction of the tritiated compounds released from the rabbit atria prelabeled with ${ }^{3} \mathrm{H}$-norepinephrine. ${ }^{46}$

(b) The second dose of the same or of another nicotinic agonist shortly after the first dose results in an attenuated or an absent release of norepinephrine. ${ }^{47}$

(c) The release of norepinephrine is inhibited by pretreatment with a ganglionic blocking agent ${ }^{45,4 B}$ or d-tubocurarine.$^{40,49}$ Hexamethonium, however, does not inhibit norepinephrine release evoked by electrical nerve stimulation. ${ }^{51}$

(d) An initial exposure of the isolated tissues to a very small concentration of a nicotinic agonist does not cause a release of norepinephrine and yet it prevents such a release when the sarne tissues are subsequently exposed to higher concentrations of the agonist. ${ }^{45}$

(e) The release of norepinephrine is dependent on the presence of ionized calcium in the bathing solution. This is in contradistinction to the calciumindependent release of norepinephrine by tyramine. ${ }^{47}$

(f) Although the release of norepinephrine ceases on continuous exposure to a nicotinic agonist, subsequent electrical stimulation of the postganglionic sympathetic fibres to the isolated heart does produce the release of norepinephrine. ${ }^{\text {sI }}$

Analogous findings have been observed in other isolated tissues. ${ }^{44.52-54}$

All of these findings in isolated organs and tissues were interpreted by postulating the existence of presynaptic nicotinic receptors on the postganglionic sympathetic terminals (Figure 1). Stimulation of these receptors leads to a release of norepinephrine. Their inactivation, however, does not affect the release of norepinephrine evoked by physiologic stimuli traversing the postganglionic sympathetic fibres. The brief duration of norepinephrine release elicited by nicotinic agonists is attributed to a short-lasting activation of the receptors and their subsequent conversion to an inactive state - desensitization. Very small concentrations of nicotinic agonists are postulated to convert the nicotinic receptors from an active (responsive) to a desensitized state without apparent previous activation. ${ }^{54}$

In addition to these presynaptic nicotinic receptors, a large body of evidence has been accumulated to show the existence of presynaptic muscarinic receptors on the postganglionic sympathetic fibres. ${ }^{55}$ Activation of these receptors inhibits the release of norepinephrine elicited either by nicotinic drugs $^{56}$ or by electrical stimulation of the postganglionic sympathetic fibres ${ }^{57}$ (Figure 1). Since acetylcholine stimulates both the nicotinic and the muscarinic presynaptic receptors on the sympathetic terminals, pretreatment with atropine is required to elicit the maximal release of norepinephrine. ${ }^{56}$ Atropine by itself has no effect on norepinephrine release elicited by electrical stimulation. ${ }^{50}$ The presynaptic muscarinic inhibitory receptors are activated by a much lower concentration of a cholinergic agonist than are the presynaptic facilitory nicotinic receptors. ${ }^{.5}$ These muscarinic receptors also show a desensitization phenomenon. ${ }^{58.59}$ A direct comparison of durations of desensitizations of the two receptor types is not available; there is some indication that the desensitization of the muscarinic receptors is shorterlasting. ${ }^{58.59}$ 


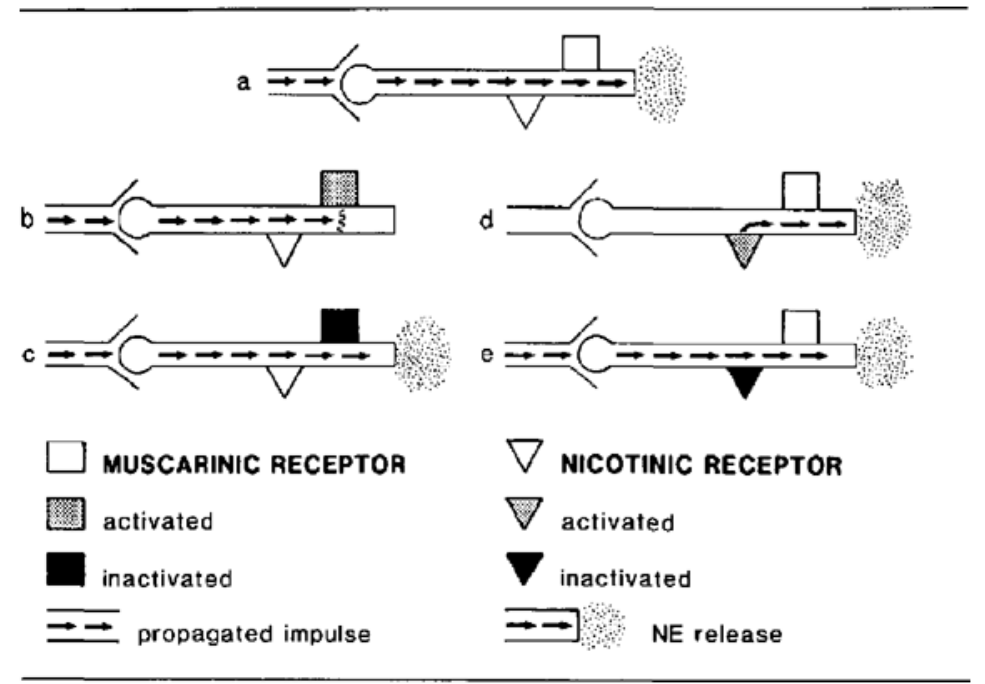

FIGURE I Schematic representation of the presynaptic cholinergic receptors on the sympathetic terminals. (a) The physiologic impulse is propagated along the postganglionic sympathetic fibre and liberates norepinephrine at the terminal. Presynaptic cholinergic receptors, one muscarinic and the other nicotinic, are diagrammed. (b) Activation of the presyntaptic muscarinic receptor attenuates or abolishes the release of norepinephrine. (c) Inactivated presynaptic muscarinic receptor does nol interfere with the reledse of norepinephrine by the physiologic stimulus. (di Activation of the presynaptic nicolinic receptor produces a brief release of norepinephrine even in the absence of physiologic stimuli. (e) Inactivated presynaptic nicotinic receptor does not interfere with the release of norepinephrine by the physiologic stimulus. See text for details.

\section{The hypothesis}

Taken together, all of these previously reported observations permit a fresh look at the pharmacologic actions of succinylcholine as a cholinergic agent. The hypothesis, explicitly stated earlier, is based on the following postulates:

(1) Succinylcholine is a cholinergic agent that, like acetylcholine, interacts with the muscarinic as well as with the nicotinic receptors. The efficacy of succinylcholine $^{60}$ may be different at different receptor sites.

(2) Succinylcholine initially activates both the postsynaptic and presynaptic receptors of either type. The initial activation is followed by a period of reduced chemosensitivity of the receptors (desensitization). ${ }^{61}$

(3) Desensitization of the nicotinic receptors outlasts that of the muscarinic receptors (no experimental proof is presently available)

The hypothesis that succinylcholine releases endogenous catecholamines is diagrammatically presented in Figure 2. Two nicotinic receptors (one postsynaptic on the endplate of the skeletal muscle and the other presynaptic on the sympathetic nerve terminal) together with two muscarinic receptors (one postsynaptic on or around the sino-atrial node and the other presynaptic on the sympathetic nerve terminal) are simultaneously exposed to succinylcholine which is assumed to have been administered by an intravenous bolus injection. Interaction of all these receptors with succinylcholine produces a very brief activation. The activation is immediately followed by a period of insensitivity to chemical stimulation - most probably desensitization of the receptors. As postulated, the desensitization lasts longer for the nicotinic than for the muscarinic receptors. Clinically, activation of the nicotinic receptors on the end-plate is manifest as a brief period of skeletal muscle activity (fasciculation) and the subsequent period of desensitization as a flaccid paralysis. Interaction of succinylcholine with the cholinoceptors at the sympathetic terminals leads to a less well defined clinical picture and is clearly dependent on the relative extent of activation and inhibition at these sites. Initial activation of the nicotinic receptors on the sympathetic terminals 


\section{DIAGRAM OF THE HYPOTHESIS}

\begin{tabular}{|c|c|c|c|}
\hline RECEPTOR & LOCATION & TIME $\rightarrow$ & RESPONSE \\
\hline \multirow{2}{*}{$\begin{array}{l}\text { NICOTINIC } \\
\text { posisynaptic }\end{array}$} & \multirow[t]{2}{*}{ End-plate } & A. & Fasciculation \\
\hline & & 1 & $\begin{array}{l}\text { Skaletal muscle } \\
\text { relaxation }\end{array}$ \\
\hline \multirow[t]{2}{*}{$\begin{array}{l}\text { NICOTINIC } \\
\text { presynaptic }\end{array}$} & \multirow{2}{*}{$\begin{array}{l}\text { Postganglionic } \\
\text { sympathetic } \\
\text { terminal }\end{array}$} & A & $\begin{array}{l}\text { Noradrenaline } \\
\text { release }\end{array}$ \\
\hline & & 1 & None \\
\hline \multirow[t]{2}{*}{$\begin{array}{l}\text { MUSCARINIC } \\
\text { presynaplic }\end{array}$} & \multirow{2}{*}{$\begin{array}{l}\text { Postganglionic } \\
\text { sympathetic } \\
\text { terminal }\end{array}$} & A & $\begin{array}{l}\text { Inhibition of } \\
\text { noradrenalline release }\end{array}$ \\
\hline & & 1 & None \\
\hline \multirow{2}{*}{$\begin{array}{l}\text { MUSCARINIC } \\
\text { posisynaplic }\end{array}$} & \multirow[t]{2}{*}{ Sino-atrial node } & A. & Bradycardia \\
\hline & & s & None \\
\hline
\end{tabular}

FIGURE 2 Diagrammatic representation of the hypothesis. $\mathrm{A}$ = Activation, $\mathrm{I}=$ Insensitivity to stimulation by a cholinergic agonist, U.R. = Proposed period of unbalanced response when the second administration of succinylcholine can activale the muscarinic but not the nicotinic receptors, $\mathrm{S}=\mathrm{IV}$ administration of succinyleholine. Response refers to the pharmacologic response produced by activation or insensitivity, above and below the horizontal line, respectively, of the concsponding receptors.

in the myocardium, and elsewhere, causes the release of norepinephrine. Initial activation of the postsynaptic muscarinic receptors at the sino-atrial node produces bradycardia. The bradycardia is brief due to the counter-action of norepinephrine released by the activation of the presynaptic nicotinic receptors. The release of norepinephrine is, however, opposed by the activation of the presynaptic muscarinic receptors on the sympathetic terminals. Due to the mutually opposing effects resulting from the activation of these cholinoceptors by succinylcholine, the net effect is small and variable.

In other words, succinylcholine usually produces balanced and clinically inconspicuous cardiovascular effects. If for whatever reasons - premedication, pharmacologic inhibition or anatomical underdevelopment of the individual receptors - one group of receptors is activated more than the other, an unbalanced and clinically manifest cardiovascular response to succinylcholine results.

\section{Clinical correlates}

Specific examples of the unbalanced haemodynamic responses to succinylcholine can now be given. It will be seen that these situations corre- spond to those described in the Introduction when succinylcholine was noted to produce adverse reactions.

(a) A second intravenous bolus injection of succinylcholine might be expected to lead to an unbalanced response if succinylcholine is administered during the interval when (1) the muscarinic receptors hacve already recovered their full chemoreactivity, and (2) the desensitization of the nicotinic receptors still persists. The expected result is bradycardia (Figure 2). Such a "window" for the bradycardic effect of the second injection of succinylcholine is consistent with clinical observations. The bradycardic response can be attributed to the activation of the postsynaptic muscarinic receptors around the sino-atrial node and of the presynaptic muscarinic receptors on the syrnpathetic terminals. The latter effect would attenuate the release of norepinephrine even when such were to be elicited by physiologic regulatory mechanisms. This interpretation offers a plausible explanation for the observation that the intramuscular or intravenous administration of atropine before anaesthesia "did not protect against bradycardia or cardiac arrest after the second dose of suxamethonium."62

(b) The bradycardic response to succinylcholine 
in infants and children indicates a deficient nicotinic response. The anatomic basis for this deficiency is seen in the lag of the development of the sympathetic terminals in the myocardium of newborn and young animals. ${ }^{63-65}$ Whereas the parasympathetic fibres to, and the postsynaptic muscarinic receptors of, the heart develop early, sympathetic terminals develop later; morphologic and pharmacologic studies $^{66.67}$ are in full conformity on this point. Norepinephrine stores in the heart during foetal development are present only in the "preterminal nerve trunks" that do not penetrate into the ventricular myocardium. ${ }^{66}$ The mature type of sympathetic innervation and pharmacologic reactivity to agents that release norepinephrine from the sympathetic terminals are first seen at different postnatal intervals in different species. ${ }^{63.68}$

(c) The so-called "self-taming" effect of succinylcholine ${ }^{32}$ can be easily understood as an onset of desensitization of the cholinergic receptors without an apparent antecedent activation. This explanation accounts also for the minimal haemodynamic effects observed when succinylcholine is administered by slow infusion or by intramuscular injection rather than as a bolus intravenously. Both of these methods of succinylcholine administration result in a slow rate of interaction of succinylcholine with the cholinergic receptors and, therefore, only minimal activation or none at all; the inactivation of the endplate receptors and, hence, muscle relaxation remain unaffected.

(d) Clinical situations most frequently associated with early haemodynamic crises after the administration of succinylcholine share an altered state of the sympathetic neryous system as their common denominator. The hypermetabolic state of a burned patient is attributed to the increased sympathetic activity ${ }^{69}$ which, if extensive and prolonged, may lead to a complete exhaustion of the adrenergic system. $^{70-72}$ In patients with tetanus, hypertensive crises and the frequent occumence of arrhythmias indicate an increased activity of the sympathetic nervous system. ${ }^{73}$ As expected, the hyperreactivity is alleviated by appropriate use of adrenergic blockers and sedation. ${ }^{74}$ Tetraplegic and, less so, paraplegic patients show supersensitivity to circulating adrenergic agonists. ${ }^{75,76}$ This supersensitivity may be ascribed to the absence of functionally active postganglionic sympathetic fibres (sympathetic denervation). In addition, in these patients the control of the sympathoadrenal system is postulated to occur "through reflex spinal mechanisms uninhibited by supraspinal centers." 77 Activation of the sympathetic nervous system was also observed in massively traumatized patients. ${ }^{78,79}$ Finally, irradiation has been shown to increase the demand for catecholamines and to deplete markedly their stores in the adrenal medulla. ${ }^{80}$

The administration of suecinylcholine to patients suffering from the conditions described can be assumed to lead to the release of endogenous catecholamines which might be very much different from that observed in normal patients. The two extremes, either an abnormally high release or an absent response, could easily lead to clinical crises. The following findings make it obvious that the interaction between the increased levels of catecholamines on one side and the increased levels of extracellular potassium and the anaesthetic agents on the other, is multifaceted:

(1) Catecholamines, especially epinephrine, cause an initial, brief hyperkalaemia followed by prolonged hyperkalaemia. ${ }^{81-85}$

(2) In dogs anaesthetized with pentobarbitone, adverse haemodynamic effects of toxic doses of potassium given by infusion are ameliorated by catecholamines. ${ }^{86,87}$

(3) In dogs during cyclopropane anesthesia ("myocardial sensitization") epinephrine does not produce ventricular tachycardia if the concomitant hyperkalaemic response to epinephrine is prevented; ${ }^{88}$ co-administration of potassium and epinephrine in these dogs, however, does produce cardiac irregularities.

Obviously, hyperkalaemia is but one biochemical change accompanying the administration of succinylcholine. As postulated, catecholamines released by succinylcholine might either produce effects on their own or modify the response to hyperkalaemia. It is the unbalanced interaction of succinylcholine with the cholinoceptors and the responses elicited by catecholamines that lead to occasional haemodynamic crises in exceptional clinical situations.

\section{Discussion}

Any attempt to explain the events leading to haemodynamic crises after the administration of succinyicholine has to account for the following clinical observations: (a) Mild haemodynamic reactions or life-threatening crises occur only during the initial several minutes after the IV injection. (b) Clinically significant haemodynamic adverse effects 
occur after the intravenous administration of customary doses of succinylcholine (about $1 \mathrm{mg} \cdot \mathrm{kg}^{-1} \mathrm{IV}$ ). The apparent lack of the dose-response relationship for these complications is well illustrated by considering patients with deficient or aberrant pseudocholinesterase: these patients are exposed to high blood levels of succinylcholine for prolonged periods of time and yet there are no reports about clinically detrimental haemodynamic effects of succinylcholine during the prolonged apnoea. The absence of such effects has not been stressed in the past. (c) Succinylcholine does not inevitably cause haemodynamic crises in all patients deemed to be at risk. So, for example, several reports document uneventful use of succinylcholine in burn patients ${ }^{90-92}$ and others document only an increased frequency of adverse reactions when compared to the control population. ${ }^{93}$ Clearly, additional factors have to be considered as contributory in the occasional production of cardiac arrest.

Direct support fot the presented hypothesis was recently obtained in anaesthetized patients. ${ }^{94} \mathrm{Fol}-$ lowing induction of anaesthesia with thiopentone and maintenance with nitrous oxide and halothane, succinylcholine was injected intravenously and ventilation controlled using a mask and reservoir bag. Plasma levels of norepinephrine in arterial blood started to rise immediately after the injection of succinylcholine, peaked at three minutes and subsequently declined to preinjection levels (tenth minute). Elevation of plasma levels of epinephrine was less marked. The data are in agreement with the notion that succinylcholine activates the presynaptic nicotinic receptors on the postganglionic sympathetic terminals. Their activation results in a sudden but brief release of norepinephrine. Since the major portion of the liberated norepinephrine is disposed of locally by the uptake into neuronal and extraneuronal tissues, plasma levels reflect only the overflow. ${ }^{95,96}$ The wash-out from the tissues accounts for the relatively delayed appearance of the peak levels of norepinephrine in plasma. Once in the circulation, however, levels of norepinephrine decrease rapidly due to its very short initial half-life in plasma (about 2 minutes). ${ }^{96}$ Since norepinephrine is released locally in the tissues, it is clear that the plasma levels of the catecholamine would not necessarily show a direct quantitative relationship to the magnitude of its effects. This point becomes very important if one considers that succinylcholine might cause release of norepinephrine directly in the myocardium.

Many lines of evidence, both clinical and experimental, support the hypothesis that the release of endogenous catecholamines contributes significantly to the adverse effects of succinylcholine. In clinical practice, cardiac arrest, rather than the collapse of the peripheral circulation, is the principal finding. If resuscitative measures (cardiac massage) are applied early, the crisis can usually be terminated after only a brief effort (e.g. ${ }^{22}$ ). The sudden but brief release of norepinephrine by succinylcholine and the very short half-life of the liberated catecholamine(s) are consistent with the underlying events in most situations. If, however, activation of the nicotinic receptors does not occur and, hence, there is no release of catecholamines, direct stimulation of the post-synaptic muscarinic receptors by succinylcholine may lead to pronounced bradycardia and even cardiac arrest in asystole (as has been observed in infants). It is important to note that similar changes in the electrocardiographic $\mathrm{T}$-wave can be produced by catecholamines as well as by hyperkalacmia. ${ }^{97-99}$ Adverse effects of catecholamines can be expected to be more pronounced in the presence of hypoxia, hypercarbia and inhalational anaesthetic agents that "sensitize" the myocardium to catecholamines. In addition, laryngoscopy, tracheal intubation (c.g. ${ }^{100}$ ) and the transfer of the patient to the operating table soon after intubation ${ }^{92,93}$ represent further sympathetic stimulation. Premedication with large doses of antimuscarinic drugs (atropine and glycopyrolate) has been shown to increase the incidence of dysrhythmias after succinylcholine-facilitated intubation. ${ }^{101}$ This finding is easily understandable in terms of the proposed interaction of succinylcholine with presynaptic muscarinic and nicotinic receptors on the sympathetic terminals: blockade of the muscarinic receptors by atropine leaves the activation of the presynaptic nicotinic receptors unopposed and consequential. Clearly, many factors influence the clinical picture of the adverse reactions to succinylcholine either by causing an additional liberation of, or altering the response to, the catecholamines.

Several experimental studies are also in full concordance with the proposed hypothesis. In agreement with a previous report, ${ }^{102}$ Tucker and Munson ${ }^{103}$ found that the threshold anhythmogenic dose of epinephrine in dogs under halothane anaes- 
thesia is markedly decreased by a preceding bolus injection of succinylcholine. The authors concluded only that succinylcholine "increases the arrhythmogenicity of epinephrine" during halothane anaesthesia. A different interpretation can now be offered. If, as presently hypothesized, succinylcholine releases endogenous catecholamines, it is to be expected that the arrhythmogenic dose of exogenous epinephrine will be proportionately reduced. Lack of arrhythmogenic effects of succinylchaline reported by Wong et al. ${ }^{104}$ is most likely due to the different mode of succinylcholine administration (infusion).

Norepinephrine may be released from its stores by mechanisms other than stimulation of the presynaptic nicotinic receptors. Independent of the nature of the release mechanism, however, the cardiac manifestations during halothane anaesthesia should be similar. This notion has been confirmed. Experiments of Condouris et al..$^{97,105,106}$ demonstrate that the initial release of norepinephrine produced by tyramine, bretylium or guanethidine precipitates ventricular arrhythmias in cats during halothane anaesthesia. Plasma potassium levels were not determined.

There are two clinical areas in which the hypothesis may lead to reinterpretation of available data. First the release of norepinephrine from the sympathetic terminals induced by activation of the presynaptic nicotinic receptors can be attenuated by a number of drugs ${ }^{47}$ In the context of the present discussion, inhibition produced by opiates, ${ }^{103}$ barbiturates, ${ }^{108}$ and by local and inhalational anaesthetic agents ${ }^{109-111}$ is noteworthy. These findings indicate that the induction of anaesthesia with ultra-short acting barbiturates and the maintenance of anaesthesia with inhalational anaesthetic agents may not only attenuate the hyperkalaemia response to succinylcholine ${ }^{112,113}$ but may also decrease the succinylcholine-induced release of catecholamines. Since all the modalities used to reduce the succinylcholineinduced fasciculation have also been shown to attenuate the release of norepinephrine elicited by stimulation of the nicotinic receptors in vitro, a similar response might be expected in vivo under clinical conditions. The recently presented clinical findings on the effects of precurarization on the prolongation of the QT interval produced by succinylcholine ${ }^{114}$ can now be explained using the proposed model. Second, catecholamines produce responses on the dencrvated muscles ${ }^{115,116}$ as well as on the extraocular muscles ${ }^{15}$ which are akin to those observed clinically after succinylcholine. Whether the effect of succinylcholine on these structures is a direct one or one indirectly facilitated by catecholamines remains to be examined.

\section{Concluding remarks}

The presented hypothesis offers an explanation for many clinical observations that have been difficult to understand. In pharmacologic terms, the hypothesis presents succinylcholine as a rather unique drug. The singularity of succinylcholine, as discussed here, is based on its transient activation and subsequent desensitization of the presynaptic cholinergic receptors on the sympathetic nerve terminals; no other drug in clinical use today is known to act similarly. Thus far, all published discussions of the interaction between succinylcholine and the nicotinic receptors have been limited to the consideration of the postsynaptic receptors localized either at the endplate or in the autonomic ganglia. ${ }^{117}$ The novel model proposed here - interaction between succinylcholine and the presynaptic cholinoceptors on the sympathetic terminals - is strongly supported by data from experiments in animals; direct support in humans under clinical conditions is necessary but may be difficult to obtain.

\section{Acknowledgements}

I appreciate many opportunities for fruitful discussions with members of the Department of Anaesthesiology. My special thanks to Professor Lucien E. Morris, F.F.A.R.C.S., for encouragement and review of the manuscript and to the reviewers of the Journal for their constructive critique. Mrs. Melissa Auen provided valuable assistance in collecting the references and secretarial help.

\section{References}

1 Dorkins HR. Suxamethonium - The development of a modem drug from 1906 to the present day. Med History 1982; 26: 145-68.

2 Calvey $T N$, Wilson $H$. Muscle relaxant drugs and their antagonists. In: Gray TC, Utting JE, Nunn JF, eds. General Anaesthesia, $4 \mathrm{kh}$ ed. Vol 1 . London: Butterworths, 1980: 319-35.

3 Durant NN, Katz RL. Suxamethonium. Br J Ansesth 1982; 54: 195-208.

4 Karz RL, Karz LE. Complications associated with 
the use of muscle relaxants. In: Orkin FK, Cooperman LH, eds. Complications in Anacsthesiology. Philadelphia: J.B. Lippincott and Co. 1983: 557-79.

5 Miller RD. Savarese JI. Pharmacology of muscle relaxants, their antagonists, and monitoring of neuromuscular function. In: Miller RD, ed. Anaesthesia. Yol. 1. New York: Churchill Livingstone, 1981: 487-538.

6 Savarese JJ, Philbin DM. Cardiovascular effects of neuromuscular blocking agents. Int Anesth Clinics 1979; 17: 13-54.

7 Smith $S E$. Neurornuscular blocking drugs in man. In: Zaimis E, ed. Neuromuscular Junction; Handbook of Experimental Pharmacology. Vol. 42. Berlin: Springer Verlag 1976: 593-660.

8 Wolts $L F$. Complications of muscle relaxants. $m$ : Katz RL, ed. Muscle Relaxants. Amsterdam: Excerpta Medica, 1975: 209-44.

9 Lim M, Churchill-Davidson HC. Adverse cffects of neuromuscular blocking drugs. In: Thornton JA ed. Adverse Reactions of Anaesthetic Drugs. Amsterdam: Excerpta Medica, 1981: 65-136.

10 Graf $K$, Ström $G$, Wăhlin A. Circulatory effects of succinylcholine in man. Acta Anaesthesiol Scand 1963; (suppl 14): 1-28.

11 Leigh MD. McCoy DD, Belton MK, Lewis GB. Bradycardia following intravenous administration of succinylcholine chloride to infants and children. Anesthesiology 1957; 18: 698-702.

12 Craythorne NWB, Turndorf $H$, Dripps $R D$. Changes in pulse rate and rhythm associated with the use of succinylcholine in anesthetized children. Anesthesiology 1960; 21: 465-70.

13 Liw LMP, DeCook TH, Goudsouzian NG, Ryan $J F$, Liu $P L$. Dose response to intramuscular succinylcholine in children. Anesthesiology 1981 ; 55: 599-602.

14 Lupprian KG, Churchill-Davidson HC. Effect of suxamethonium on cardiac rhythm. Br Med J $1960 ; 2: 1774-7$.

15 Williams $C H$, Deutsch $S$, Linde $H W$, Bullough $J W$, Dripps $R D$. Effects of intravenously administered succinylcholine on cardiac rate, rhythm, and arterial pressure in anesthetized man. Anesthesiology 1961; 22: 947-54.

16 Winter $C$, Ahrefeld FW. Vergleichende EKGund Kaliumuntersuchungen bei intermittierender Injektion von Suceinylcholin-chlorid und Dauertropfinfusion. Anaesthesist 1974; 23: 249-52.
17 Eyrich $K$, Friedemann $M$, Scholler KL. Nebenwirkungen von Succinylcholin auf das Herz. Anaesthesist 1965; 14: 303-7.

18 Phillips $H S$. Physiological changes noted with the use of succinylcholine chloride, as a muscle relaxant during endotracheal intubation. Anesth Analg 1954; 33: 165-77.

19 Schoenstadt DA, Whitcher $C E$. Observations on the mechanism of succinylcholine-induced cardiac arrhythmias. Anesthesiology 1963; 24: 358-62.

20 Gronert GA, Theye RA. Pathophysiology of hyperkalaemia induced by succinylcholine. Anesthesiology 1975; 43: 89-99.

21 Cairoli VJ, Ivankowich AD, Vucicevic D, Patel $K$. Succinylcholine-induced hyperkalaemia in the rat following radiation injury to muscle. Anesth Analg 1982; 61: 83-6.

22 Fergusson RF, Wright DJ, Willey RF, Crompton $G K$, Grant IWB. Suxamethonium is dangerous in polyneuropathy. Br Med J 1981; 282: 298-9.

23 Cullen $D J$. The effect of pretreatment with nondepolarizing muscle relaxants on the nequromuscular blocking action of succinylcholine. Anesthesiology 1971; 35: 572-8.

24 Blitr $C D$, Carlson $G L$, Rolling GD, Hameroff $S R$, Otto $C W$. A comparative evaluation of pretreatment with non-depolarizing neuromuscular blockers prior to administration of succinylcholine. Anesthesiology 1931; 55: 687-9.

25 Foster CA. Muscle pains that follow administration of suxamethonium. Br Med J 1960; 2: 24-5.

26 Haldia KN, Chatterji S, Kackar SN. Intravenous lidocaine for prevention of muscle pain after succinylcholine. Anesth Analg 1973; 52: 849-52.

27 Wikinski $R$, Usubiaga $L J$, Usubiaga JE, Wikinski $J A$. Prevention of succinylcholine fasciculation with local anesthetics. Anesthesiology 1965; 26:3-7.

28 Eisenberg $M$, Balsley $S$, Katz RL. Effects of diazepam on succinylcholine-induced myalgia, polassium increase, creatine phosphokinase elevation, and relaxation. Anesth Analg 1979; 58: 314-7.

29 Erkola $O$, Salmenperä $M_{1}$ Tammisto $T$. Does diazepam pretreatment prevent succinylchcline-induced fasciculations? A doublc-blind comparison of diazapam and tubocurarine pretreatments. Anesth Analg 1980; 59: 932-4.

30 Fahmy NR, Malek NS, Lappas DG. Diazepam prevents some adverse effects of succinylcholine. Clin Pharmacol Ther 1979; 26: 395-8. 
31 Verma RS, Chatterji S, Mathur N. Diazepam and succinylcholine-induced muscle pains. Anesth Analg 1978; 57: 295-7.

32 Baraka A. Self-taming of succinylcholine-induced fasciculations. Anesthesiology 1977; 46: 292-3.

33 Karhunen $U$, Heinonen $J$, Tammisto $T$. The effect of tubocurarine and alcuronium on suxamethoniuminduced changes in cardiac rate and rhythm. Acta Anaesthesiol Scand 1972; 16:3-10.

34 Mathias JA, Evans-Prosser CDG, Churchill-Davidson $\mathrm{HC}$. The role of the non-depolarizing drugs in the prevention of suxamethonium bradycardia. Br J Anacsth 1970; 42: 609-13.

35 Zaimis $E$, Hed $S$. Depolarizing neuromuscular blocking drugs. In: Zaimis E, ed. Neuromuscular Junction: Handbook of Experimental Pharmacolngy Vol. 42. Berlin: Springer Verlag, 1976: 365-420.

36 Taylor $P$. Ganglionic stimulating and blocking agents. In: Gilman AG, Goodman LS, Gilman A, eds The Phamacological Basis of Therapeutics. 6th ed New York: Macmillan Pubi. Co., 1980: 211-9

37 Comroe $\mathrm{JH} \mathrm{Jr}$. The pharmacological actions of nicotine. Ann N Y Acad Sci 1950; 90: 48-51.

$38 \mathrm{Su} C$. Actions of nicotine and smoking on circulation. J Pharmac Ther 1982; 17: 129-41.

39 Gebber GL. Neurogenic basis for the rise in blood pressure evoked by nicotine in the cat. J Pharmacol Exp Ther 1969; 166: 255-63.

40 Hoffmann F, Hoffmann EF, Middleton S. Talesnik $J$. The stimulating effect of acetylcholine on the mammalian heart and the liberation of an epinephrinelike substance by the isolated heart. Am J Physiol 1945; 144: 189-98.

41 Richardson JA, Wood $E F$. Relcase of norepinephrine from the isolated heart. Proc Soc Exp Biol Med 1959; 100: 149-51.

42 Ferry $C B$. The sympathomimetic effect of acetylcholine on the spleen of the cat. J Physiol 1963; 167: 487-504.

43 Sarantos-Laska C, McCulloch MW, Rand MJ. Facilitatory effect of nicotine on adrenergic neuroeffector transmission in the isolated ear artery of the rabbit. J Pharm Pharmacol 1980; 32: 92-6.

44 Steinsland OS, Furchgott RF. Vasoconstriction of the isolated rabbit ear artery caused by nicotinic agonists acting on adrenergic neurons. J Pharmacol Exp Ther 1975; 193: 128-37.

45 Löffelholz $K$. Autoinhibition of nicotinic release of noradrenaline from postganglionic sympathetic nerves. Naunyn-Schmiedeberg's Arch Pharmak 1970; 267: 49-63.

46 Sarantos-Laska C, Majewski $H$, McCulloch MW, Rand M.I. Mechanism of noradrenaline release from rabbit atria by nicotinic agonists. Arch Int Pharmaciodyn 1980; 247: 294-305.

47 Löffelholz $K$. Relcase induced by nicotinic agonists In: Patton DM, ed. The Release of Catecholamines from Adrenergic Neurons. Oxford: Pergamon Press, 1979: 275-301.

48 Starke $K$. Regulation of noradrenaline release by presynaptic receptor systems. Rev Physiol Biochem Pharmacol 1977; 77: 1-124.

49 Lee WC, Shideman FE. Mechanism of the positive inotropic response to certain ganglionic stimulants. J Pharmacol Exp Ther 1959; 126: 239-49.

50 Fozard JR, Muscholl E.. Effects of several muscarinic agonists on cardiac performance and the relcasc of noradrenaline from sympathetic nerves of the perfused rabtit heart. Br J Pharmacol 1972; 45: 616-29.

51 Löffelholz $K$. Nicotinic drugs and postganglionic sympathetic transmission. Naunyn-Schmiedeberg's Arch Pharmak 1970; 267: 64-73.

52 Ikushima S, Muramatsu I, Sakakibara Y, Yokotani $K$, Fujiwara $M$. The effects of d-nicotine and l-isomer on nicotinic receptors. J Pharmacol Exp Ther 1982; 222: 463-70.

53 Kirpekar SM, Garcia AG, Prat JC. Action of nicotine on sympathetic nerve lerminals. J Pharmacol Exp Ther 1980; 213: 133-8.

54 Steinsland $O S$, Furchgot $R F$. Densensitization of the adrenergic neurons of the isolated rabbit ear artery to nicotinic agonists. J Pharmacol Exp Ther 1975; 193: 138-48.

55 Muscholl E. Pcripheral muscarinic control of norepinephrine release in the cardiovascular system. Am J Physiol 1980; 239: H713-20.

56 Lindmar R, Löffelholz K, Muscholl E. A muscarinic mechanism inhibiting the release of noradrenaline from peripheral adrenergic nerve fibres by nicotinic agents. Br J Pharmac Chemother 1968; 32: 280-94.

57 Löffelholz $K$, Muscholl E. A muscarinic inhibition of the noradrenaline release cyoked by postganglionic sympathetic nerve stimulation. Naunyn-Schmiedeberg's Arch Pharmakol 1969; 265: 1-15.

58 Jalife J, Hamilton AJ, Moe GK. Desensitization of the cholinergic receptor at the sino-atrial cell of the kitten. Am J Physiol 1980; 238: H439-48.

59 Steinsland OS, Furchgot RF, Kirpekar SM. Inhibi- 
tion of adrenergic neurotransmission by parasympathomimetics in the rabbit ear artery. J Pharmacol Exp Ther 1973; 184: 346-56.

60 Goldstein A, Aronow L, Kalman SM. Principles of Drug Acrion. 2nd ed. New York: John Wiley and Sons, 1974: 99.

61 Rang HP, Ritter JM. On the mechanism of desensitization at cholinergic receptors. Mol Pharmacol 1970; 6: 357-82.

62 Viby-Mogensen J, Wisborg K, Gabrielsen J, Spotoft $H$. Halothane anaesthesia and suxamethonium. I: The significance of preoperative atropine administration. Acta Anaesthesiol Scand 1976; 20: 129-40.

63 Friedman WF. The intrinsic physiologic properties of the developing heart. Prog Cardiovasc Dis 1972; 15: 87-111.

64 Pappano AJ. Ontogenic development of autonomic neuroeffector transmission and transmitter reactivity in embryonic and fetal hcarts. Pharmacol Rev 1977; 29: 3-33.

65 Mackenzie E, Standen NB. The postnatal development of adrenoceptor responses in isolated papillary muscles from rat. Pflïger's Arch 1980; 383: 185-7.

66 Friedman WF, Pool PE, Jacobowitz D, Seagren $S C$ Braunwald $E$. Sympathetic innervation of the developing rabbit heart. Circulation Res 1968; 23: 25-32.

67 Glowinski J, Axelrod J, Kopin IJ, Wurman RJ. Physiological disposition of ${ }^{3} \mathrm{H}$-norepinephrine in the developing rat. J Pharmacol Exp Ther 1964; 146: 48-53.

68 Lipp JA, Rudolph AM. Sympathetic nerve dcrclopment in the rat and guinea-pig heart. Biol Neonate 1972; 21: 76-82.

69 Wilmore DW, Long JM, Mason AD Jr, Skreen RW, Pruitt BA. Catecholamines: Mediator of the hypermetabolic response to thermal injury. Ann Surg 1974; 180: 653-9.

70 Goodall $M C C$. Stone $C$, Haynes $B W$ Jr. Urinary output of adrenaline and noracrenaline in severe thermal burns. Ann Surg 1957; 145: 479-87.

71 Goodall $M C C$. Haynes BW Jr. Adrenal medullary insufficiency in severe thermal burn. J. Clin In. vest $1960 ; 39: 1927-32$

72 Goodall $M C C$. Moncrief $J A$. Sympathetic nerve depletion in severe thermal injury. Ann Surg 1965; 162: 893-900.

73 Corbett JL, Kerr JH, Prys-Roberts C, Crampton Smith A, Spalding JMK. Cardiovascular disturbances in severe tetanus due to overactivity of the sympathetic nervous system. Anaesthesia 1969; 24: 198-212.

74 Prys-Roberts C, Kerr JH, Corbett JL, Crampton Smith A, Spaulding IMK. Treatment of sympathetic overactivity in tetanus. Lancet 1969; 1:542-5.

75 Debarge $O$, Christensen $N J$, Corbett $J L$, Eidelman $B H$, Frankel HL, Mathias CJ. Plasma catecholamines in tetraplegics. Paraplegia 1974; 12:44-9.

76 Mathias CJ, Frankel HL, Christensen NJ, Spalding $J M K$. Enhanced pressor response to noradrenaline in patients with cervical spinal cord transection. Brain 1976; 99: 757-70.

77 Levin BE, Martin BF, Natelson BH. Basal sympatho-adrenal function in quadriplegic man. J Autonom Nerv Syst 1980; 2: 327-36.

78 Millar RA, Benfey BG. The fluorimetric estimation of adrenaline and noractrenaline during haemorrhagic hypotension. $\mathrm{Br} J$ Anaesth 1958; 158-65.

79 Benedict $C R$, Grahame-Smith DG. Plasma noradrenaline and adrenaline concentrations and dopamine- $\beta$ hydroxylase activity in patients with shock due 10 septicaemia, trauma and haemorrhage. Quart J Mcd New Series 1978; 47: 1-20.

80 Goodall McC, Long $M$. Effect of whole-body $x$ irradiation on the adrenal medulla and the hormones adrenaline and noradrenaline. Am J Physiol 1959; 197: $1265-70$.

81 Rosa RM. Silva P, Young JB et al. Adrenergic modulation of extrarenal potassium disposal. $\mathrm{N}$ Engl J Med 1980; 302: 431-4.

82 Silva $P$, Spokes $K$. Sympathetic system in potassium homeostasis. Am J Physiol 1981: 241: F151-5.

83 Lim M, Linton RAF, Band DM. Continuous intravascular monitoring of epinephrine-induced changes in plasma potassium. Anesthesiology 1982; 57: $272-8$.

84 Sterns RH, Cox M, Feig PV, Singer I. Internal potassium balance and the control of the plasma potassium concentration. Medicine 1981; 60: $339-54$

85 Todd EP, Vick RL. Kalemotropic effect of epinephrine: analysis with adrenergic agonists and antagorists. Am J Physiol 1971; 220: 1964-9.

86 Lockwood RH, Lum BKB. Effects of adrenergic agonists and antagonists on potassium metabolism. J. Pharmacol Exp Ther 1974; 189: 119-29.

87 Lum BKB, Lockwood RH. Effects of nicotine and sympathomimetic amines on potassium intoxication. J Pharmacol Exp Ther 1972; 181: 147-54. 
88 O'Brien GS, Eid CH, Murphy QRJr, Meek WJ. EITecl of elimination of hepatic circulation on cyclopropaneepinephrine ventricular tachycardia and arterial plasma potassium in dogs. J Phamacol Exp Ther 1954; 112 374-7.

89 Davis $L D$, Helmer $P R$, Murphy $Q R$. Role of potassium in cyclopropane-epinephrine ventricular tachycardia. Anesthesiology 1964; 25: 54-8.

90 Benway RE, Maier ES, Jenicek JA. Anesthetic management of the severely burned patient. Am J Surg 1962; 103: 677-87.

91 Epstein BS, Rudman HL, Hardy DL, Downes $H$. Comparison of orotracheal intubation with tracheostomy for anesthesia in patients with face and neck burns. Anesth Analg 1966; 45: 352-9.

92 Lowenstein $E$. Succinylcholine administration in the burned patient. Anesthesialogy 1966; 27: 494-6.

93 Finer $B L$, Nylén BO. Cardiac arrest in the treatment of burns, and report on hypnosis as a substitute for anesthesia. Plast Recon Surg 1961; 27: 49-55.

94 Nigrovic V, MCCullough LS, Wajskol A, Levin $J A$, Martin $J T$. Succinylcholine-induced increases in plasma catecholamine levels in humans. Anesth Analg 1983; 62: 627-32.

95 Cryer PE. Physiology and pathophysiology of the human sympathoadrenal neuroendocrine system. N Engl J Med 1980; 303: 436-44.

96 Esler $M$. Assessment of sympathetic neryous function in humans from noradrenaline plasma kinetics. Clin Sci 1982; 62; 247-54.

97 Condouris GA, Kopia GA. Cardiac arrhythmias induced by guanethidine in cats anesthetized with halothane. Eur J Pharmacol 1980; 68: 257-65.

98 Cruickshank JM, Neil-Dwyer G, Stott AW. Possible role of catecholamines, corticosteroids, and potassium in production of electrographic abnormalities associated with subarachnoid haemonhage. Br Heart J 1974; 36: 697-706.

99 Heros RC, Zervas NT. Subarachnoid hemorrhage. Ann Rev Med 1983; 34: 367-75.

100 Miller Forbes A, Dally FG. Acute hypertension during induction of anaesthesia and endotracheal intubation in rormotensive man. Br $\mathrm{J}$ Anaesth 1970; 42: 618-24.

101 Mirakhur RK, Clarke RSJ, Elliott J, Durdee $J W$. Atropine and glycopyronium premedication. Anaesthesia 1978; 33: 906-12.

102 Sharma PL, Narang RS. Effect of succinylcholime, gallamine and d-tubocurarine on adrenaline-evoked ventricular arthythmias in dogs under halothanenitrous oxide anacsthesia. Indian J Med Res $1968 ; 56: 1272-81$.

103 Tucker WK, Munson ES. Effects of succinylcholine and d-tubocurarine on epinephrine-induced arthythmias during halothane anesthesia in dogs. Anesthesiology 1975; 42: 41-4.

104 Wong KC, Wyte SR, Martin WE, Crawford EW. Antiarrhythmic effects of skeletal muscle relaxants Anesthesiology $1971 ; 34: 458-62$.

105 Kopia GA, Condouris GA. Guanethidine- and tyramine-induced arthythmias in halothane anesthetized cats. Pharmacologist 1978; 20: 186.

106 Condouris GA, Oritz $J$, Lyness W. Cardiac arrhythmias produced by bretylium in cats anesthetized with halothane. Eur J Pharmacol 1979; 55: 93-7.

107 Kumakura K, Karoum F, Guidoni A, Costa E. Modulation of nicotinic receptors by opiate receptor agonists in cultured adrenal chromaffin cells. $\mathrm{Na}$ ture $1980 ; 283 ; 489-92$.

108 Göthert M. Riekesmann JM. Inhibition of noradrenaline release from sympathetic nerves by pentobarbital. Experientia 1978; 34: 382-4.

109 Göthert M, Dührsen V, Rieckesmann JM. Ethanol, anaesthetics and other lipophilic drugs preferentially inhibit 5-hydroxytryptamine- and acetylcholine-incuced noradrenaline release from sympathetic nerves. Arch Int Pharmacodyn 1979; 242: 196-209.

110 Göthert $M$. Effects of halothane on the sympathetic nerve terminals of the rabbit beart. NaunynSchmiedeberg's Arch Pharmacol' 1974; 286: 125-43.

111 Haeusler $G$, Thoenen $H$, Haefely W, Huerlimann A. Electrosecretcry coupling at the release of noradrenaline from adrenergic nerve fibers by nicotinelike acting strbstances. Naunyn-Schmicdeberg 's Arch Pharmak Exp Path 1969; 263: 217-8.

112 Bali $I M$, Dundee $J W$. Immediate changes in plasma potassium, sodium and chloride induced by intravenous induction agents. Br J Anaesth 1974; 46: 929-33.

113 Srovner $J$, Endresen $R$, Bjelke $E$. Suxamethonium hyperkalaemia with different induction agents. Acta Anaesthesiol Scand 1972; 16: 46-50.

114 Saarnivaara $L$, Lindgren $L$. Prolongation of QT interval during induction of anacsthcsia. Acta Anaesthesiol Scand 1983; $27: 126-30$.

115 Bowman WC, Nott $M W$. Actions of sympatho- 
mimetic amines and their antagonists on skeletal muscle. Pharmacol Rev $1969 ; 21: 27-72$.

116 Evans $R H$. Smith $J W$. The effect of catecholamines on the influx of calcium and the development of tension in denervated mouse diaphragm muscle. Br J Pharmacol 1976; 58: 109-16.

117 Bowman WC. Non-relaxant properties of neuromuscular blocking drugs. Br J Anaesth 1982; 54: $147-60$.

\section{Résumé}

On propose une hypothèse pour expliquer les réactions hémodynamiques indésirables à la succinylcholine: $I$ interaction de la succinylcholine avec les récepteurs cholinergiques amènerain le karguage de catéchoiamines endogènes (surtout la norépinéphrine). Les manifestations cliniques de cette interaction dépendraient de I'importance du larguage. En se basant sur des données publiées de l'expérimentation animale avec des agents muscariniques el nicotiniques, on propose un mécanisme pour ce larguage de norépinéphrine. L'interaction de la succinylcholine avec le récepteur nicotinique ou muscarinique provoque une activation initiale suivie d' une phase d'insensibilité chimique. L'activation des récepteurs pré-synaptiques nicotiniques dans la terminaison sympathique post-ganglionnaire amène une libération brève de norépinéphrine. L'activation des récepieurs muscariniques pré-synaptiques produit l'effet opposé. Chez la majorité des patients, ces actions opposées sunt bulancées et le résultar final est de peu d' importance clinique. Une réponse non équilibrée amenant des manifestations cliniques peul survenir si les deux types de cholinocepteurs sont activés différemment. 